\title{
SALAFÎ WOMEN AND ISLAMIC MOVEMENTS: The Case of Salafism in Jama'ah al-Khidhir
}

\author{
Shinta $\mathcal{N}$ urani \\ Institut Agama Islam Negeri Pekalongan, Indonesia \\ E-mail: shinta.nurani@iainpekalongan.ac.id
}

\begin{abstract}
One of the ideology and Islamic movement in Indonesia in 1980s was Salafi. This article focuses on a group called Majlis al-Khidhir led by a young Salafist named Abu Ahmad Muhammad al-Khidhir. This article is talking about Salafi women starting to search for and converse of identity as well as their patterns of interest to be Salafi women in carrying out Islamic sharia and the role of al-Khidhir in their lives into Salafis in accordance with the Quran, hadith, and the attitude of the al-salaf al-sâlih. The result reveals that the identity and politics of al-Khidhir Salafi women movement has four dimensions. First, Salafi is not a revolutionary movement that opposes Pancasila and especially for Salafî women to obey their husband as ulil amri gives a great responsibility to educate his wife and children. Second, Salafi has different symbols cloths (dress or gamis which covers her body, shows no body shape, not transparent that are plain black from top to bottom, wearing veils or niqâb and socks). Third, Jama'ah al-Khidhir identified his followers using a familiar greeting, including 'akhi' for men and 'ukhti' for women refer to the symbol of piety and value standards for mutual respect among members of the Salafi community. Fourth, al-Khidhir empowers Salafi women are active in da'wah by using writings and images which are distributed through various media, especially social media WhatsApp, Facebook and Telegram in order to attract the interest of womens to follow the path of al-salaf al-sâlih.
\end{abstract}


Salah satu ideologi dan gerakan Islam di Indonesia pada 1980-an adalah Salafî. Dalam artikel ini fokus pada sebuah kelompok Salafî bernama Majlis al-Khidhir yang dipimpin oleh seorang Salafì muda bernama Abu Ahmad Muhammad al-Khidhir. Artikel ini membahas tentang perempuan Salafî mulai dari bagaimana pencarian dan konversi identitas sampai bagaimana pola minat mereka menjadi perempuan Salafi dalam menjalankan syariah Islam dan peran al-Khidhir dalam kehidupan mereka untuk menjadi Salafi yang sesuai dengan Alquran, hadis, dan sikap al-salaf al-sâlih. Hasil artikel ini bahwa identitas dan politik gerakan wanita Salafî al-Khidhir memiliki empat dimensi. Pertama, Salafî bukanlah gerakan revolusioner yang menentang Pancasila dan khususnya perempuan Salafi untuk mematuhi suaminya sebagai ulil amri yang bertanggungjawab mendidik istri dan anaknya. Kedua, Salafî memiliki simbol identitas pakaian yang berbeda (gamis yang menutupi tubuhnya, tidak memberi bentuk tubuh, tidak trasnparan, berwarna hitam polos dari atas ke bawah, mengenakan kerudung atau niqâb dan kaus kaki). Ketiga, Jama'ah alKhidhir mengidentifikasi pengikutnya menggunakan sapaan akrab, 'akhi' (laki-laki) dan 'ukhti' (perempuan) untuk menunjukkan simbol kesalehan dan saling menghormati di antara anggota komunitas Salafî. Keempat, alKhidhir memberdayakan wanita Salafì aktif dalam dakwah menggunakan tulisan dan gambar yang didistribusikan melalui berbagai media, terutama media sosial WhatsApp, Facebook dan Telegram untuk menarik minat wanita dalam mengikuti jalan al-salaf al-sâlih.

Keywords: Islamic movement; Jama'ah al-Khidhir; Salafî women

Received: October 14, 2018; Accepted: October 2, 2019

\section{Introduction}

After the decline of the Orde Baru, in order to mark the revolution and freedom of Indonesian nation, a lot of Islamic organizations appear (Bruinessen 2002, 3). These organizations are of Islamic background but with different ideology, such as Moderate Islam, Liberal-Progressive Islam, and Radical-Fundamentalist Islam (Boy 2009, xxi). All of them want to present Islam in accordance with their ideology and Islamic da'wah movement they adhere to. One of the ideology and Islamic movement in Indonesia in 1980s was Salafî as the group and phenomenon which has captured the public attention (Sunarwoto 2016, 203). 
The studies of Salafism in Indonesia can be mapped into three. First, writing that focuses on Salafî movements and identities (Duderija 2014; Rumman 2014; Iqbal 2014; Rosadi 2015, Ahmadi, Hefni and Mutrofin 2019). Second, the study of media and Salafî da'wah (Hefner 2003; Bräuchler 2004; Nisa 2013; Sunarwoto 2016). Third, the study of Salafî women is supported by Anabel Inge's book entitled The Making of a Salafi Muslim Woman: Path to Conversion mentioning that becoming Salafî women negotiate teaching and realities in Britain (Inge 2017). As explained by Inge, Sunesti, Hasan, and Azca in their article Young Salafi-Niqabi and Hijrah: Agency and Indetity Negotiation focuses on the study of young millennial of Salafî-niqabi's life in Surakarta and their strategies in dealing with power relation in their everyday lives (Sunesti, Hasan, and Azca 2018). Unlike previous article, this study aims at drawing how Salafî women perform their roles as Salafî starting from the conversion of their identity up to how they follow their Islamic sharia under the Islamic movement of al-Khidhir. This study focuses on a group called Majlis al-Khidhir led by a young Salafist named Abu Ahmad Muhammad al-Khidir bin Salim alLimboriy Hafizhahullah. Al-Khidhir group has many followers, most of them are women, youths (18-24 years old), and university students in college in Bekasi, Indonesia.

All female students from different campus background gather in the same cope called al-ghuraba (strange) because they are all far away from the worldly life. This community will save women from unlimited modernity under the name of globalization. This what makes them (Salafî women in Jama'ah al-Khidhir) active in following dawrah study directly or via telegram, and practice it according to what they have learned in al-Khidhir (Nina 2018) for their daily life as a Salafist of Jama'ah al-Khidhir

\section{Salafî and Jama'ah al-Khidhir}

Salafî (salaf; pl. Aslaf) means predecessors, progenitors, ancestors (Wehr 1976, 423). It refers to a specific group or movement indicated by the adherence to alsalaf al-sâlih (holy ancestors of the Muslim community) in the first three generations and literal interpretation of Quran and hadith. Salafî is a big Islamic movement in the Middle East and other regions. It comes from the reform movement by Muhammad ibn 'Abd al-Wahhâb collaborated with Ibn Sa'ûd family in the 18th century in the Arabian Peninsula. This movement focuses on the opinion of Ibn Taymiyah, 
Muhammad ibn Qayyim al-Jawziyah and Muhammad ibn 'Abd al-Wahhâb. Salafîs desire to emulate the Prophet's way of life literally. The intellectual genealogy of Salafî comes to Aḥmad ibn Hanbal (d. 855), Ibn al-Taymiyah (d. 1328), Ibn Qayyim al-Jawziyah (d. 1350), Ibn 'Abd al-Wahhâb (d. 1792), Contemporary Middle Eastern Muslim scholars such as 'Abd al-Azîz ibn Bâz (d. 1999), Nâsir al-Dîn al-Albânî (d. 1999), Muhammad Șâliḥ al'Uthaymîn (d. 2001), Muqbil ibn Hâdî al-Wadi'î (d. 2001), and others.

The Salafî movement in Indonesia emerged in the mid-1980s as a consequence of the Salafî transnational da'wah movement, which gained public attention after the decline of Orde Baru in 1998 (Hasan 2006, 4751). This is the phase of the rise of Salafî groups and movements in Indonesia through several Muslim leaders, especially Saudi Arabian and Yemen alumni. The person who first started this Salafî mission was Abu Nida. He held dawrah and halaqah for scholars at several universities in Yogyakarta, established the Majelis At-Turots Al-Islamy foundation, and built a Salafî pesantren (Islamic boarding school) to serve da'wah and other social activities.

In subsequent developments, the Salafî movement emphasizes more on cadre aspects (Soage 2009, 295), so that the Salafî da'wah movement in Indonesia continues along with the return of a large number of LIPIA (Institute of Studies for Islam and Arabic) graduates from universities in the Middle East, especially Saudi Arabia (Hasan 2006, 47-51). After returning from Saudi Arabia, they took part in the community by teaching in Islamic education institutions. Other institutions that support the development of Wahhâbî teachings in Indonesia are the Islamic Sciences and Arabic Institute (LIPIA), founded in 1980. The institution, which is fully sponsored by the Saudi Arabian government, is one of the centers of Wahhâbî ideology in Indonesia. They spread Wahhâbî teachings under the banner of Salafî da'wah.

Then, the Salafî group formed Laskar Jihad in 2000, in response to the failure of the state to end religious conflict in Ambon, Maluku (Sirozi 2005; Umam 2006), in addition to strengthening Salafî political power (Shokri 2016, 3-4). This development brought the Laskar Jihad commander, Ja'far Umar Thalib to become the leader of the movement. However, the increasing influence of Thalib challenged the authority of Abu Nida. Then in 2002, Laskar Jihad was dissolved after the fatwa of Rabî‘ ibn Hâdî alMadkhalî, a respected Salafî scholar in Saudi Arabia. This fatwa came at the request of a number of Thalib's associates and students who considered 
him to diverge from the actual Salafî method. Since then, according to Noorhaidi Hasan, Salafî in Thalib network have been divided into three groups: Luqman Baabduh network (former deputy commander of Laskar Jihad), Dzulqarnain network (former section head of the Laskar Jihad fatwa), and Abu Turob al-Jawi network (former member of Laskar Jihad). From the discordance, each network formed small groups with different study centers (Hasan 2006, 87). In this paper, the focus is on a small group of Abu Turob al-Jawi networks based in Bekasi. This group calls itself Jama'ah al-Khidhir.

Jama'ah al-Khidhir is a name for the followers of Majlis al-Khidhir led by a young Salafist named Abu Ahmad Muhammad al-Khidhir ibn Salim al-Limboriy Hafizhahullah. He was born in Limboro, West Seram District, Maluku Islands, on September 4, 1983. When he was born, his parents named him Khidhir taken from the name of the Prophet Khidhir. However, when he entered Madrasah Ibtidaiyyah (Islamic Elementary School) Muhammadiyyah in Limboro (1996), the teacher mistakenly wrote his name, and he was written under the name of Haider Mursalim. Then, he continued his education at SMP (Junior High School) Temi Muhammadiyah (1999) and Madrasah Aliyah (Islamic Senior High School) Al-Fatah Ambon, then he moved to SMA (Senior High School) Muhammadiyah Limboro (2002).

Abu Ahmad Muhammad al-Khidhir ibn Salim al-Limboriy received his bachelor's degree after studying at the Surabaya Health Polytechnic. His hobby is reading religious books and taking time to attend Islamic studies assemblies held by campus mosques. After al-Khidhir completed his studies in 2005 and obtained a degree in electromedic engineering, he then focused on studying Islam from several Islamic boarding schools such as Ma'had As-Sunnah Bajirupa Makassar, Ma'had Umar bin Khattab Sugihan Lamongan, Ma'had Darul Atsar Banyutengah Gresik, and Ma'had Dhiya'us Sunnah Cirebon. During his study at several Islamic boarding schools, he had written several books which at that time he was still using the name Khidhir al-Limbory with his first speech, Abul 'Abbas.

After Khidhir al-Limbory studied in several Islamic boarding schools in Indonesia, in 2008-2013, he studied Islam in Dâr al-Hadith Dammaj, So'dah, Yemen. While studying in Dammaj, he changed his name to Muhammad and his nickname (kunyah) is Abu Ahmad. In Dâr al-Hadîth of Yemen, he studied religion a lot under the guidance of the Ahl al-Sunnah wa al-Jamâ'ah scholars. In early 2014, he moved to the As-Sunnah Sa'awan 
Madinah Sakaniyah Șan'a Mosque then moved to Jâmi' al-Fatḥ Baihan Șan'a.

In 2015, al-Khidhir returned to Indonesia, he did da'wah through hadith studies to the surrounding community by establishing Majlis alKhidhir to spread Salafî teachings sourced from his teachers in the Yemen Network especially Abu Turob Network as former members of Laskar Jihad. The existence of this majlis initially only held dawrah and meetings regularly in certain places. The study carried out by Khidhir al-Limbory was followed by many students and the public who then choose to emigrate to Salaf Sâlih or often referred to Salafîs.

Furthermore, Khidhir al-Limbory married his student named Andini Sagita Prapanca, who lived in Pekalongan but actively followed the study of Majlis al-Khidhir while she was still a student. From that marriage, they had a son born on Wednesday, February 22, 2017 M/25 Jumâd alAwwal $1438 \mathrm{H}$ and his son was named Ahmad al-Khidhir.

Nowadays, Jama'ah al-Khidhir has experienced a significant increase because many people are curious about the religious sciences, especially the science of hadith, so they will often follow Islamic studies conducted by Majlis al-Khidhir. Majlis al-Khidhir has a main study conducted every Sunday morning at 9 AM in Perumahan Kemang Pratama, Bekasi. However, now, this routine is not only held in one place but also in mosques and mushalla, including An-Nur Mosque, Bogor and al-Hidayah Mushalla, Bekasi. Majlis al-Khidhir discussed many things about Islamic teachings such as monotheism (tawhîd), aqeedah, fiqh, nahwu, and hadith. The source of aqeedah is from al-Uș̂ul al-Thalâthah meanwhile the study of monotheism (tawhîd) is taken from al-Tawhîd. Both are written by al-Imâm Muhammad ibn Sulaymân al-Najdî. The Book of Arba'în Nawawî is used to deepen the study of hadith. The study of fiqh uses Bulûgh al-Marâm by Ibn Hajar while the Book of Darus al-Lughah is used for the study of Nahwu (Prapanca 2018). In addition to studies through dawrah or halaqah, Majlis al-Khidhir also uses online chatting platform Telegram through the channel http://t.me/majaalisalkhidhir to broadcast the Salafîs da'wah.

In addition, Majlis al-Khidhir also has its own book publishing named Maktabah al-Khidhir to support al-Khidhir productivity in writing books about Salafî from various perspectives. The books written by Abu Ahmad al-Khidhir and published by Maktabah al-Khidhir are Peran Pemuda dalam Penyebaran Agama, Bingkisan untuk Umat dalam Menghadapi Ujian- 
Ujian Dahsyat Menjelang Hari Kiamat, Bintang-bintang Penerang Perahuku dalam Mengarungi Samudera Ilmu, Beginilah Dakwah Nabi, Panduan Singkat tentang Tata Cara Shalat, Hukum-Hukum Seputar Jenazah Disertai dengan Jawaban terhadap Beberapa Masalah, Ringkasan Keterangan tentang Perjalanan Hidup Abul 'Abbas Harmin, Hukum-Hukum tentang Shalawat, Dalil-dalil Populer, dan Perjalanan Hidup Abul 'Abbas Harmin. That is all about Majlis alKhidhir in which among its members are young Salafî women in around 18-24 years old who are in the period of searching for and conversion of their identity as individuals and as part of society.

\section{Method}

This study was carried out by doing in-depth interview and observation. In-depth interviews are needed to understand the subject from his perspective so that the subject can express his feelings and point of view openly. Some questions are directed at exploring the things they experienced and felt after joining the Salafî al-Khidhir congregation. In the field study, I made direct observation from January until February 2018 by becoming a part of Jama'ah al-Khidhir and following routine studies. In attending the study, I interviewed six active female followers of Jama'ah alKhidhir who were able to provide and share their experiences of being a Salafî woman. The interviews did not take place formally and systematically. Enriching the data, I entered into an active participant of Jama'ah alKhidhir and made a personal approach with each respondent who had long been an active follower of Jama'ah al-Khidhir. Most of these followers (around 65\%) are students or youth around 18-24 years old. Although many are also adults or elders (around 30\%) and the rest are children who are their next generation.

As for this study, I focused more on six people in the age range around 18-24 who participated in al-Khidhir's study in Bekasi area. They are: a) Dini (23 years old; alumni of the Polytechnic of Purwokerto) the wife of cleric (leader) of Jama'ah al-Khidhir; b) Fatma and Indah are two active students that are still studying at one of Islamic colleges in Department of Islamic Education in Bekasi; c) the other two were Nina (a student of Islamic campus) and Sari (student of public campus) who are still on leave because of certain problems; and d) the last one is Rizka who is completing a thesis from a private university in Bekasi while still actively participate in Salafî studies. They are young women who actively follow and become part of Jama'ah al-Khidhir. 


\section{Salafî Women Profile of Jama'ah al-Khidhir}

The presence of manhaj Salafi and Majlis al-Khidhir is a blessing and the most beautiful guidance of Allah swt., which not everyone even very few people get this opportunity. Therefore, they will not waste the gift in addition to sticking to the practice of Salafî teachings as well as participating in preaching the teachings and inviting their friends to join them. As Fatma and Indah did, they boarded in the same place but they came from different regions. Fatma comes from Java while Indah is from outside Java. Fatma first got to know Majlis al-Khidhir when she was passing through a house. She saw many people in that house and heard faintly the da'wah which made her moved to listen to. Finally Fatma asked one of the congregation and was welcomed to participate. Fatma regularly followed the study until she felt very comfortable and calm. According to her, the life of this world has been increasingly damaged. She even regretted her dark past that she had been involved in love and courtship which caused her to lose the most important thing of her future (Fatma 2018).

Then, Fatma invited Indah after Indah told that she had just broken up with her boyfriend. This moment was used by Fatma to invite Indah to take part in a study that would be more reassuring. Finally, Indah, who was often with Fatma, taking part in the Salafî study also feels comfortable in Jama'ah al-Khidhir community (Indah 2018). In this case, their motivation to join Jama'ah al-Khidhir is because they want to avoid worldly disturbances that can damage them both physically and mentally. If it is examined more broadly, in this case moral panic (Cohen 2004, 1) plays a significant role as a motivation for them to join this Salafî community.

The experience told by Nina also leads to the same motivation because she lives in a broken-home family. Her parents divorced that made her only live with her mother until one day her mother remarried. They found out later that her stepfather is a temperamental person who often mistreats his own family. On that basis, Nina experienced panic and moral fear of herself and her future after witnessing the severe violence and crime. Nina saw that the Salafî community would be able to save herself from the moral savagery that occurred in this world because Nina was convinced that the (male) husband from Salafî was more aware of religion and had good morals (Nina 2018).

Unlike Nina's story, Sari became a Salafî for a different reason. According to her, she was born from a very poor family. She could not 
afford the demands and fashionable modern life as her friends. She was unable to compete with his peers or other people. Even for schools, Sari had to rely on a government or school scholarship to go to college. She also had to become an online motorcycle taxi driver. In campus, Sari felt that her friends left her out because she could not adjust with her friends' lifestyle (Sari 2018). Rizka has the same motivation. She feels that she is an ordinary and simple person, so it is more appropriate to join with the similar type of people. This motivation can be drawn at one point that they experience a crisis of femininity (Hall et al. 1978, 16). This is because they as women feel different from other women. They feel that they were born in an environment that does not support them as women so they cannot afford to compete with others out there who are very different and more feminine. They think that being with fellow women who share similar experiences or stories, will make their lives more peaceful than having to see the world of women who are all feminine, beautiful, fashionable, elegant, surrounded by abundant materials, shopping and hangout here and there, and others. Furthermore, Rizka defines beautiful and feminine as follow:

"True women are those who are able to maintain themselves not only being beautiful and abundant in material. Moreover, the woman has valuable assets that must be maintained, for example by covering her face using a veil because that is the best natural make-up and the best face shield. In contrast to women outside who use cosmetics made from chemicals and it is not clear that they are halal to be displayed to public. Veil makes the face white and clear with Allah's permission. Moreover, the veil is adorned with noble character and gentleness and obedience to the Quran and hadith" (Rizka 2018).

Thus, from different campus backgrounds and with their respective motivations, they gather in one and the same shade under a group called "al-ghuraba" (foreign) because they are alienated from worldly life. This community will save them from the tide of infinite modernity under the guise of globalization. The motivations that encourage their spirit to unite in Jama'ah al-Khidhir include haunting moral panic and femininity crisis. They reinforce and help each other because of the sense of shared affinities that they have as a community that is considered exclusive. In this community too, they find a fresh breeze of calm, comfort, and the most comfortable place to live in this world. In fact, they felt that in Jama'ah al- 
Khidhir they found their identity as a true Muslim woman which they had been looking for so long.

\section{Salafî Women in Searching For and Conversion of Identity}

Women have an important position in Muslim youth identity politics because they are responsible for reproducing culture and Islam. In relation to Islam, young women are at the center of Muslims struggle. AlKhidhir in his book states that the da'wah focusing on tawhîd nowadays is received and welcomed by youth in majority. This is because Islam is a religion that has great attention and high respect for young people who have well-built and strong opinions in upholding the religion of tawhîd. Allah describes this attention in the Quran with the story of Prophet Ibrâhîm (Q.S. al-Anbiyâ' [21]: 51-67) (al-Khidhir 2017a, 9 and 29). Therefore, the $d a^{\text {'wah }}$ carried out by Majlis al-Khidhir was aimed more at youth, especially students.

Young people around $18-24$ years old are in the age of maturity and searching for identity. As students, they often have direct contact with their social environment and face questions about deep identity. According to Inge, university is a social and religious space with various opportunities to start something new, rediscover, and evaluate yourself. Therefore, they try to build their best socio-religious identity which is described as a search for identity as the followers of true or pure Islam (Inge 2017, 80).

In this case, they try adjusting to the existing religious traditions to the challenge of modernity. Moreover, many changes coming with various fluctuation in lives and interpretations of multidimensional Islam, make many women experience moral panic and femininity crisis. Sometimes, it causes them to lose their identity as a Muslim woman. Then, they have a lot of questions such as "Who am I?", "Am I a true Muslim?", "What is the indicator of a true Muslim woman?", "Where will I find my identity as a Muslim woman who is shalihah and taat?", and other similar questions.

The questions lead Salafî women to find alternative answers. Moreover, there is a modernization as a very shocking development and a contribution to the increasing variety of social life complexities. The disappearance of traditional authority along with the growth of rationality results in a change how people perceive life. Modernization is seen as a general process in which communal action based on identity or Gemeinschaft replaced by rationally regulated social action or Gesellschaft, (Weber 1956, 51) discovers changes that will occur to attitudes that bring 
disappointment to the world. Therefore, some people looked for the answers through religion. This is because it has become a deep belief that religion, especially through Quran and hadith, which is șâlih li kulli zamân wa makân will be able to solve all conflicts that have occurred since long time ago. The more young people feel 'upset' or worried about their future or even experience an identity crisis, the more they will definitely seek and choose to follow religious activities that are being carried out by da'wah groups such as Majlis al-Khidhir. They do hope that after actively joining the religious activities, they immediately find answers to their questions so that they automatically find their identity.

From the interview result with the respondents, the process of searching for identity began with the interest in following Salafî study carried out by Majlis al-Khidhir. In the beginning, they were interested in joining group just because they wanted to know or they were curious. It is because they often listened to da'wah carried out near their boarding house. According to Fatma and Sari, following Islamic da'wah such as alsalaf alsâlih will make their lives better in terms of mental, economic, education, social, careers, and problem related to future mate. In contrast, Nina began with a negative view of Jema'ah al-Khidhir who were always closed to the public as if they felt the most perfect Islam. This is because people especially women of that group usually wear outer clothes such as black loose-fitting dress (gamis), veils or niqâbs and socks. Nina was unable to imagine how hot and complicated the Salafî clothes are. However, it leads her to be interested in following the study in al-Khidhir. Whereas Dini and Indah are following Salafi studies because of the social ties with their friends who are also the active members of Jama'ah al-Khidhir.

The example of interest in becoming Salafî women in Jama'ah alKhidhir above can be concluded that there are two possibilities including the closeness and social ties with active Salafî members which play role in the identity conversion process (Dawson 2006, 239). Conversion is a complex process as the realization of a new identity involving the context of biography, vulnerability, and motives (Sahr 2006, 75). Absolutely, the previous socialization, relationships and life experiences play an important role in addition to the religious actors (Gooren 2006, 52), in this case Abu Ahmad al-Khidhir. The transformation of society through their choice and assertiveness combines the idea of someone's true self with the search for Islam and forces them to study Islam through various networks. 
Klandermans and Oegema stated that these networks include social networks, friendships, relatives, and the environment that continue to play an important role in the mobilization of self-identity into Salafî women (Klandermans and Oegema 1987, 520).

The identity of being Salafî women is formed in Salafî community of Majlis al-Khidhir who try to distinguish their existence from other mainstream Muslim groups in Indonesia by establishing what they believe to be a muslimah shalihah and religious Muslim. The quality of Salafî women's lifestyles, such as their lives in accordance with the Quran, hadith, and the behavior of al-salaf al-sâlih marks their conscious orientation about the accentuation of differences and the struggle between Islam, modernity, and culture in wider society (Nisa 2013, 244).

Michel Foucault claims that along with the progress of history, such fights have increasingly happened in discourses and symbols, in a mode that has no goal and is indirect (Foucault 1972, 98). Symbolic statements can suggest a complex and contradictory layer of meaning, so being the center of the negotiation of the identity and role of each individual is the key to negotiation about the opportunities that arise when tradition has changed. Responding to the opportunity of tradition change and negotiation of Salafî identity is very important by referring to his ancestor, Muhammad ibn Ṣâlih al-Uthaymîn who said that what is called Salafî is Ahl al-Sunnah wa al-Jamâ'ah. Definition of Ahl al-Sunnah wa al-Jamâ'ah is salaf in belief, even though people are late until the Day of Judgment, if their existence is above the method of the Prophet and his companions, then he is a Salafî (alKhidhir 2017b, 7-8).

Moreover, the role of Salafî women members also strengthens the identification and participation in Jama'ah al-Khidhir so as to make members of the congregation feel possessed and provide a sense of security, relationship, comfort, trust and solidarity among fellow of Jama'ah alKhidhir. Therefore, the identity of Salafî women in Jama'ah al-Khidhir is increasingly strong in addition to being internally built through negotiating Salafi identities and the role of active members as well as the politics of Islamic sharia movements implemented in their daily lives.

\section{Salafî Women: al-Khidhir Islamic Politics and Social Movement}

The emergence of Jama'ah al-Khidir cannot be separated from the influence of the discordance of Salafî movement in Indonesia. It causes small group of Salafîs to rise with the leadership of Abu Turob al-Jawi based 
in Bekasi, who called themselves Jama'ah al-Khidhir. Jama'ah al-Khidhir is a term for followers of Majelis al-Khidhir led by a young Salafî, Abu Ahmad Muhammad Al-Khidhir. The main objective of this group establishment was none other than to spread Salafî teachings originating from its teachers in Yemeni Network, especially the Abu Turob Network as a former member of Laskar Jihad. By spreading Salafî, Jama'ah al-Khidir is expected to be able to produce a formalistic and positivistic understanding of Islam.

Hence, this movement hopes to implement sharia comprehensively to make a religious society and strongly support the literal interpretation of the Quran (Fealy 2004, 106-7), because they assume that the way to get an understanding of the true Islamic teachings is by holding on to the direct meaning of the word contained in the holy text. To reach that goal, Khidhir al-Limbory movement holds dawrah and meetings regularly in certain places, to invite students and the community to hijrah and choose the way of al-salaf al-șâlih (salafis).

This hijrah summons will later expand the network of Jama'ah alKhidhir movement in spreading Salafî al-Khidir teachings in holding the principles of Salafî women doctrine and practicing the teachings of religion in accordance with the rules of Quran and sunna carried out by the Messenger of Allah and the Companions, as well as the early generations of Muslims (al-salaf al-sâlih) because the first Muslim generation are the best generation. So, they must follow the sunna of the Prophet and al-salaf alsâlih to carry out Islamic teachings consistently in their daily lives. The newly emerging of the elite Salafî women will emphasize the implementation and practice of Islamic sharia law as a religious identity. It may be also influenced by Modernist thinking to purify the Muslim community from traditional non-Islamic practices, the elite Muslim turned to sharia (Othman 2005, 112-3) as the best way in the pure sharia Islamization process. This is because, for them, the reality of Muslims who are left behind is the effect of ignoring the truth of Islam as taught by alsalaf alsâalih and returning to the doctrine of al-salaf al-sâlih will make the Muslim community able to resolve the irrelevance in their faith practices.

Therefore, they will adjust themselves in revealing the sunna so that people will no longer think that sunna is symbols of extreme people or symbols of deviant sect, for example, wearing niqâb or veil. According to alKhidhir, by wearing niqấb everyday, people will find it as habit of women at the Prophet Muhammad era and the negative suspicion will disappear by 
itself. Women at that time, liked men who were righteous (sâlih), regardless of status, without seeing the material, the most important thing was devotion (taqwâa), knowledge, and practice. They easily get such men because their parents are righteous and understand religion. In contrast to the present era, the age in which people with religious knowledge become minorities. This condition is proven to occur today as the hadith:

The Messenger of Allah șalla Allah 'alayh wa sallam said, "Nearly your time is contested like a group of predators fighting over their food." Then, someone asks: "Is that due to our small number?" "Even you are many, but you are just like foam and God has pulled out the trembling feeling from the heart of your enemies against you. And Allah has given the disease of al-Wahan in your heart." Someone asked: "Oh Messenger of Allah, what is al-Wahan?", The Prophet șalla Allâh 'alayh wa sallam said: "They love the world and fear death."

The aforementioned hadith reveals that nowadays, there are so many Muslims in number, but they are so much busy with the world. They are excited about the world and afraid of death so they fear the enemy and their enemies are no longer afraid of them (al-Khidhir 2017d, 68-70). Thus, the many number of Muslims sometimes is only to be proud of the world when in fact their fate is very sad.

Next, in case of social interaction, Salafî women wearing niqẩb do not require themselves to close with society. They may leave the house, attend events and activities if their activities are related to Islam. For example, circumcision, birth, death and others, Salafî women can be at the front position in helping their neighbors and relatives to cook and prepare for the activity. This is because, according to al-Khidhir, the true religion of Islam teaches us to interact with the community and fill it with good morals (al-Khidhir 2018). The Messenger of Allah said:

"Gather with people with good character" (al-Tirmidhî No. 1987 and Ahmad 5/153, al-Tirmidhî said that the hadith was hasan sahịhh).

In addition, al-Khidhir also emphasized the need to help and protect fellow Muslims, especially to help oppressed people (al-Khidhir 2017c, 40). In this case, the Prophet Muhammad also forbade those who were strong from oppressing those who were weak because such actions included the behavior of the Jâhiliyah that had occurred in the time of Prophet Moses and the time of the Prophet until this time, there are still many strong people oppress the poor ones. 
The main point that reflects the identity and politics of the Salafî women movement has five dimensions. First, Salafî is not a revolutionary movement that opposes the status quo by claiming to break down ideologies other than Islam such as Pancasila. Nevertheless, he claims to establish a moral message by purifying structures at the level of individuals, families, or communities. In his fatwa, Abu Ahmad al-Khidhir called on his followers especially to women to obey the government as a form of obedience to Allah and His Messenger. Whether the government did good to them or not, they still obeyed them in case of goodness (al-Khidhir $2017 \mathrm{~d}, 54-55)$. If the government does good to them because they spread the religion of God then the good belongs to them too. God has said:

"Oh you who believe! Obey Allah and obey the Rasul of Allah, as well as the ulil amri among you" (Q.S. al-Nisâ'[4]: 59).

And the Messenger of Allah stated:

"Whoever obeys me, he has obeyed Allah and whoever rebels against me, he has been disobedient to Allah, whoever obeys my "amir" (who is Muslim) then he obeys me and whoever is disobedient to my "amir", then he is disobedient to me" (Narrated by al-Bukhârî from Abû Hurayrah).

For Salafî women, al-Khidhir asked to obey their leaders specifically for husband as family heads. A husband as ulil amri for his wife gives a great responsibility to educate his wife and children in accordance with the demands of Allah and His Messenger. The wife must be obedient to her husband in matters that are containing goodness in religion. For example, when he invited to jimâ' (intercourse), ordered to pray, fast, sadaqah, wear Muslim clothing (Islamic headscarves and wearing niqâb), attend science assemblies, and other forms of instruction as long as they are in line with sharia (Dini 2018). This is precisely what will bring Heaven to her, like the words of the Prophet salla Allâh 'alayh wa sallam:

"If a wife does five daily prayers, fasts in the month of Ramadan, keeps her genitals (keeps her honor), and obeys her husband, surely she will enter Heaven from whichever door she wants" (Narrated by Ibn Hibbân).

Second, Salafî emphasizes a strong identity to its followers by being different in appearance. In relation to identity, they are intentionally dissimilar in terms of cloths and beards. The outer clothes of women are loose-fitting dress (gamis) that are plain black from top to bottom, wearing 
veils or niqâb and socks. When they are in the community who mostly wear hijab, they must too. In contrast, when they are in a situation that does not require wearing hijab, they can unveil their hijab.

In some cases, there are other muslim women who wear hijab only in public places such as business place, hospital, place of gold jewellery maker or one of tailor women's clothing. In reality, they show their face and both arms as if they were next to their husband or mahram.

We also can see some women on board (i.e. planes coming from outside Saudi Arabia) not wearing hijab, except when the plane landed at one of the airports in the Arab country. It is as if hijab was derived from customs (Arab Nation) and not from the fundamentals of religious teachings. They were dressed but actually naked, like women wearing thin material clothes that depict their posture (femininity) or fit clothing that shows the body curves, such as hips and arms. Women's clothing, however, covers her body, shows no body shape, as well as the skeleton of her limbs because of her thick and wide form. Salafî women was obliged to cover her whole body from the male who is not her mahram. Salafî women's clothing is not garnished by the jewellery that draws attention when leaving the house so as not to be included in tabarruj (showing off). They must use clothes that is not too thin (transparent). It is not a too-fit garment that brings the form of limbs, as mentioned in the hadith of Muslims from the prophet șalla Allâh 'alayh wa sallam:

"The two groups of the inhabitants of hell that I have not seen, (the first group) are women who dress (in essence) as if they are naked, seduce and tease, that their heads like hump camel. They do not go to heaven and do not even smell it. And (the second group) is the man who was like a cow's tail" (Narrated by Muslim)

Third, Jama'ah al-Khidhir identified his followers using a familiar greeting, including 'akhi' for men and 'ukhti' for women. Akhi and ukhti are not only to distinguish between the gender. More than that, there is an ideological content that is built by Salafis related to the use of those words. The words refer to the symbol of piety and value standards for mutual respect among members of the Salafi community. The symbols summarized in the words akhi and ukhti are then understood collectively in that community and are used as a method of da'wah to introduce and familiarize the use of Arabic within community. From the use of the word, it also 
contains consequences in the form of disciplinary values and selfembodiment, including in positioning themselves as an ideal man or woman or as brothers and sisters in the Salafî community. Internally, the word also has implications for the use of the word assalâmu'alaykum and various other words such as 'afwan, and so on to build a bond of solidarity into the Salafî community.

Fourth, al-Khidhir actively empowers his followers by encouraging them to actively participate in Salafî da'wah. This is done to form a locus of the strength of the resistance of Salafî da'wah in Majlis al-Khidhir by exploring certain ways in order to fulfill the objectives of Salafî da'wah. The Salafî women are active in da'wah by using writings and images which are distributed through various media, especially social media which are carried out through WhatsApp, Facebook, and Telegram in order to attract the interest of womens to follow the path of al-salaf alsâalih. Da'wah carried out by them is guided by the following basic principles: reviving Islamic sciences (al-ilm); purify monotheism and eradicate polytheism (al-tawhîd); revive the sunna and eradicate heresy (al-sunnah); purification of treasures of Islamic sciences (al-tasfiyah); spread the teachings of Islam that is straight (al-da'wah); encourage kindness and prevent evil (amr ma'rûf nahy munkar); and purifying the soul (al-tazkiyah).

As a consequence, the political principle of al-Khidhir is clear as the petitioner of knowledge and spread it to obey the government as a form of obedience to Allah and His Messenger (al-Khidhir 2017d, 54-55), whether or not the government does good to them. They determine to obey government in good things. If the government does good to them because they spread the religion of Allah then it is good for them too. Al-Khidhir also emphasized the importance of people as a superior community based on tawhîd, rather than just relationship. In fact, al-Khidhir never imposed a certain power on his group, but they built strength together. This means, because Salafî is a religious group movement, then this should not be considered as a phenomenon of consolidation and homogeneous domination (Porta 2006, 20) of one person against another in one group. Power is never in the hands of anyone. It is never adapted to commodities or wealth and they are always in a position to live and exercise power as Salafî simultaneously. This is done to form a locus of power involved in the reaction of the power and persistence of Salafî da'wah in Majlis al-Khidhir which continuously explores certain ways in order to meet the objectives. 
Furthermore, they strengthen the social movement politics and $d a^{\text {'wah }}$ of Majlis al-Khidhir in an era called Global Village which means that in advanced communication media, it allows millions of people around the world to feel close (John 1996, 324). Therefore, Global Village also influenced Salafî da'wah activities of Majlis al-Khidhir in the public space created by al-Khidhir. The diversity of da'wah activities is definitely driven strongly by other elements, i.e. the $d a^{\prime}$ wah media which is more likely to be understood as a channel used by both individual and communal da'wah actors to convey their message. Therefore, there are many groups of Islamic da'wah movements including Salafî group that transform Salafî da'wah movement not only through dawrah or halaqah and pengajian in mosques or majlis taklim, but also using new media. The use of new media in Salafî $d a^{\text {wwah }}$ is used by al-Khidhir through his Telegram channel to issue fatwa, $d a^{\prime}$ wah and interact with followers on social media.

\section{Conclusion}

The Salafî women of Jama'ah al-Khidhir mutually support and help one another because of the similar feelings they have as a community that is considered exclusive. Besides, they seek to establish their best socio-religious identity as an effort to find their identity as followers of true Islam to adapt to religious traditions and the challenges of modernity. The model of interest in becoming Salafî women of Jama'ah al-Khidhir occurs because of the closeness and social ties with active Salafî members who play an important role in this process of identity conversion.

A key point reflects the self-identity and political movement of Salafî women Majlis al-Khidhir has four dimensions. First, Salafî is not a revolutionary movement that opposes the status quo to break down ideology other than Islam but they build a moral message by purifying structures at the individual, family or community level. Al-Khidhir calls on his followers especially to women to obey the government in goodness to practice the command of Allah and His Messenger. Second, Salafî emphasizes a strong identity to its followers by being different in appearance through women's clothing in the form of loose-fitting black plain dress (gamis) from top to bottom, wearing veils or niqâb and socks. Third, Jama'ah al-Khidhir identified his followers using the concept of close relationship among Muslims with a familiar greeting, i.e. 'akhi' for men and 'ukhti' for women. Fourth, al-Khidhir actively empowers his followers by encouraging 
them to actively participate in Salafî da'wah not only through dawrah or halaqah but also by using Telegram channel to issue fatwa, da'wah and interact with followers on social media.

\section{References}

Ahmadi, Rizka, Wildani Hefni, and Mutrofin. 2019. Indonesian Global Ikhwan's Reception and Expression Toward Sunnah Poligamy in Online Media." Ulul Albab: Jurnal Studi Islam 20(1): 70-94.

DOI: http://dx.doi.org/10.18860/ua.v20i1.5660

Al-Khidhir, Abu Ahmad Muhammad. 2017a. Peran Pemuda dalam Penyebaran Agama. Bekasi: Maktabah al-Khidhir.

Al-Khidhir, Abu Ahmad Muhammad. 2017b. Bintang-Bintang Penerang Perahuku dalam Mengarungi Samudra Ilmu. Bekasi: Maktabah alKhidhir.

Al-Khidhir, Abu Ahmad Muhammad. 2017c. Beginilah Dakwah Rasulullah. Bekasi: Maktabah al-Khidhir.

Al-Khidhir, Abu Ahmad Muhammad. 2017d. Bingkisan untuk Umat dalam Menghadapi Ujian-Ujian Dahsyat Menjelang Hari Kiamat. Bekasi: Maktabah al-Khidhir.

Boy, Pradana. 2009. Para Pembela Islam. Depok: Gramata Publishing.

Bräuchler. 2004. "Islamic Radicalism Online: The Moluccan Mission of the Laskar Jihad in Cyberspace." The Australian Journal of Anthropology 15(3): 267-85.

DOI: https://doi.org/10.1111/j.1835-9310.2004.tb00098.x

Cohen, S. 2004. Folk Devils and Moral Panics. London: Routledge.

Dawson, Lorne L. 2006. "Who Joins New Religious Movement and Why Twenty Years of Research and What Have We Learned?" In Noorhaidi Hasan, Laskar Jihad: Islam, Militancy, and the Quest for Identity in Post-New Order Indonesia. New York: Cornell Southeast Asia Program, 239.

Duderija, Adis. 2014. "Neo-Traditional Salafi Qur'an-Sunnah Hermeneutic and The Construction of a Normative Muslimah Image." Hawwa 5(2): 289-323. 
DOI: https://doi.org/ 10.1163/156920807782912526

Fealy, Greg. 2004. "Islamic Radicalism in Indonesia: The Faltering Revival?" Southeast Asian Affairs: 104-21.

Foucault, Michel. 1972. Power/Knowledge. New York: Pantheon.

Gooren, Henri. 2006. "The Religious Market Model and Conversion: Towards a New Approach.” Exchange 35(1): 39-60.

DOI: https://doi.org/10.1163/157254306776066915

Hall, Stuart et al. 1978. Policing the Crisis. London: Macmillan.

Hefner, Robert W. 2003. "Civic Pluralism Denied? The New Media and Jihadi Violence in Indonesia." In New Media in the Muslim World: The Emerging Public Sphere, eds. Dale F. Eickelman and John W. Anderson. Bloomington: Indiana University Press, 158-179.

Hasan, Noorhaidi. 2006. Laskar Jihad: Islam, Militancy, and the Quest for Identity in Post-New Order Indonesia. New York: Cornell Southeast Asia Program.

Hasan, Noorhaidi. 2002. "Faith and Politics: The Rise of the Laskar Jihad in the Era of Transition in Indonesia." Indonesia 73: 145-69.

DOI: https://doi.org/10.2307/3351472

Inge, Anabel. 2017. The Making of a Salafi Muslim Woman: Paths to Conversion. New York: Oxford University Press.

Iqbal, Asep M. 2014. "Internet, Identity, and Islamic Movements: the Case of Salafism in Indonesia." Islamika Indonesiana 1(1): 81-105.

DOI: https://doi.org/10.15575/isin.v1i1.42

John, Little. 1996. Theories of Human Communication Fifth Edition. New York: Wadsworth Publishing Company.

Klandermans, Bert and Dirk Oegema. 1987. "Potentials, Networks, Motivations, and Barriers: Steps Towards Participation in Social Movements." American Sociological Review 52(4): 519-31.

DOI: http://dx.doi.org/10.2307/2095297

Meijer, Roel. 2009. Global Salafism Islam's New Religious Movement. London: C. Hurst Company. 
Nisa, Eva F. 2013. "The Internet Subculture of Indonesian Face-veiled Women." International Journal of Cultural Studies 16(3): 241-55.

DOI: https://doi.org/10.1177/1367877912474534

Othman, Norani. 2005. Muslim Women and the Challenge of Islamic Extremism. Selangor: Sisters in Islam.

Porta, Mario Daini Donatella Della. 2006. Sosial Movement an Introduction. United State: Blackwell Publishing.

Rosadi, Aden. 2015. "Gerakan Salaf." Toleransi: Media Komunikasi Umat Bergama 7(2): 194-205.

DOI: http://dx.doi.org/10.24014/trs.v7i2.1430

Rumman, Mohammad Abu. 2014. I am A Salafi: A Study of the Actual and Imagined Identities of Salafis. Amman: Friedrich-Ebert-Stiftung.

Sahr Wohlrab, Monica. 2006. "Symbolizing Distance: Conversion to Islam in Germany and the United States." In K. Van Nieuwkerk, Women Embracing Islam: Gender and Conversion in the West. Austin: University of Texas Press, 75.

Sirozi, M. 2005. "The Intellectual Roots of Islamic Radicalism in Indonesia: Ja'far Umar Thalib of Laskar Jihad (Jihad Fighters) and His Educational Background.” Muslim World 95(1): 81-120. DOI: https://doi.org/10.1111/j.1478-1913.2005.00080.x

Soage, Ana Belén. 2009. "Hasan Al-Banna And Sayyid Qutb: Contiunity Or Rupture?." The Muslim World 99(2): 294-311.

DOI: https://doi.org/10.1111/j.1478-1913.2009.01270.x

Shokri, Mehdi. 2016. "Islam And Politics: The Case Of The Islamic State." Studia Humana 5(2): 3-12.

DOI: https://doi.org/10.1515/sh-2016-0006

Sunarwoto. 2016. "Salafi Dakwah Radio: A Contest for Religious Authority." Archipel 91: 203-20.

Sunesti, Yuyun, Noorhaidi Hasan, and Muhammad Najib Azca. 2018. "Young Salafi-Niqabi and Hijrah: Agency and Identity Negotiation." Indonesian Journal of Islam and Muslim Societies 8(2): 173-97.

DOI: https://doi.org/10.18326/ijims.v8i2.173-198 
Umam, Saiful. 2006. "Radical Muslims in Indonesia: The Case of Ja'far Umar Thalib and the Laskar Jihad." Explorations: A Graduate Student Journal of Southeast Asian Studies 6(1): 1-26.

Van Bruinessen, Martin. 2002 "Genealogies of Islamic Radicalism In PostSuharto Indonesia." South East Asia Research 10(2): 117-54.

DOI: https://doi.org/10.5367/000000002101297035

Weber, Max. 1956. From Max Weber: Essays in Sociology. London: Routledge.

Wehr, H. 1976. A Dictionary of Modern Written Arabic. New York: Spoken Language Services Inc.

Interview with Abu Ahmad al-Khidhir as the founding of Jama'ah alKhidhir, January 6, 2018.

Interview with Andini Sagita Prapanca as the wife of Khidhir al-Limbory, January 6, 2018.

Interview with Fatma as the follower of Jama'ah al-Khidhir, January 6, 2018.

Interview with Indah as the follower of Jama'ah al-Khidhir, January 6, 2018.

Interview with Nina as the follower of Jama'ah al-Khidhir, January 6, 2018.

Interview with Sari as the follower of Jama'ah al-Khidhir, January 6, 2018.

Interview with Rizka as the follower of Jama'ah Al-Khidhir, January 6, 2018.

Interview with Dini as the follower of Jama'ah Al-Khidhir, January 6, 2018. 